\title{
The Objects That Remain
}




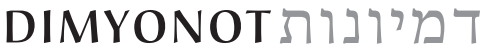

Jews and the Cultural Imagination

\author{
Samantha Baskind, General Editor \\ Editorial Board \\ Judith Baskin, University of Oregon \\ David Biale, University of California, Davis \\ Katrin Kogman-Appel, Ben-Gurion University of the Negev \\ Laura Levitt, Temple University \\ Ilan Stavans, Amherst College \\ David Stern, Harvard University
}

Volumes in the Dimyonot series explore the intersections, and interstices, of Jewish experience and culture. These projects emerge from many disciplines-including art, history, language, literature, music, religion, philosophy, and cultural studiesand diverse chronological and geographical locations. Each volume, however, interrogates the multiple and evolving representations of Judaism and Jewishness, by both Jews and non-Jews, over time and place.

Other titles in the series:

David Stern, Christoph Markschies,

Heinrich Heine, Hebrew Melodies, trans. and Sarit Shalev-Eyni, eds., The Monk's

Haggadah: A Fifteenth-Century Stephen Mitchell and Jack Prelutsky, Illuminated Codex from the Monastery of Tegernsee, with a prologue by Friar Erhard von Pappenheim

Ranen Omer-Sherman, Imagining the Kibbutz: Visions of Utopia in Literature and Film

Jordan D. Finkin, An Inch or Two of Time: Time and Space in Jerwish Modernisms

Ilan Stavans and Marcelo Brodsky, Once@9:53am: Terrorin Buenos Aires

Ben Schachter, Image, Action, and Idea in Contemporary Jewish Art

illus. Mark Podwal

Irene Eber, Jeres in China: Cultural Conversations, Changing Perspectives

Jonathan K. Crane, ed., Judaism, Race, and Ethics: Conversations and Questions

Yael Halevi-Wise, The Multilayered Imagination of A. B. Yehoshua

David S. Herrstrom and Andrew D. Scrimgeour, The Prophetic Quest: The Windores of Jacob Landau, Reform Congregation Keneseth Israel, Elkins Park, Pennsylvania 


\section{The Objects That Remain Laura Levitt}


Sections of this book were previously published as "Revisiting the Property Room: A Humanist Perspective on Doing Justice and Telling Stories," Conversations: An Online Journal of the Center for the Study of Material and Visual Cultures of Religion (2015); "Miki Kratsman, Diptych from The Resolution of the Suspect," MAVCOR Journal 2, no. 1 (2018); "Evidence: Doing Justice," Bulletin for the Study of Religion 41 (November 2012): 37-44; and "Ritual and Rites in Holocaust Commemoration: A Silence in the Archive," Bulletin for the Study of Religion, February 12, 2016.

The views or opinions expressed in this book, and the context in which the images are used, do not necessarily reflect the views or policy of, nor imply approval or endorsement by, the United States Holocaust Memorial Museum.

Library of Congress Cataloging-in-Publication Data

Names: Levitt, Laura, 1960- author.

Title: The objects that remain / Laura Levitt.

Other titles: Dimyonot (University Park, Pa.)

Description: University Park, Pennsylvania : The Pennsylvania State University Press, [2020] | Series: Dimyonot: Jews and the cultural imagination | Includes bibliographical references and index.

Summary: "A personal memoir and examination of the ways in which the material remains of violent crimes, from rape to genocide, inform our experience of, and thinking about, trauma and loss"-Provided by publisher.

Identifiers: LCCN 2020029004 | ISBN 9780271087825 (cloth)

Subjects: LCSH: Levitt, Laura, 1960- | Violent crimes-Psychological aspects. | Personal belongings-Psychological aspects. | Psychic trauma. | Loss (Psychology)

Classification: LCC HV6493.L48 2020 | DDC 362.8801/9-dc23

LC record available at https://lccn.loc.gov/2020029004

Copyright (C) 2020 Laura Levitt

All rights reserved

Printed in the United States of America

Published by The Pennsylvania State University Press,

University Park, PA 16802-1003

The Pennsylvania State University Press is a member of the Association of University Presses.

It is the policy of The Pennsylvania State University Press to use acid-free paper. Publications on uncoated stock satisfy the minimum requirements of American National Standard for Information Sciences-Permanence of Paper for Printed Library Material, ansi z39.48-1992. 
In honor of my mother,

Phyllis Levitt, and all those who hold her memory and carry her legacy forward. 
A sudden death is one way-a terrible way, I suppose-of freezing the details of a life. While writing Jane I became amazed by the way one act of violence had transformed an array of everyday items-a raincoat, a pair of pantyhose, a paperback book, a wool jumper-into numbered pieces of evidence, into talismans that threatened at every turn to take on allegorical proportions.

-Maggie Nelson, The Red Parts, 120 